\title{
Is the diet of a typical shredder related to the physical habitat of headwater streams in the Brazilian Cerrado?
}

\author{
Wander R. Ferreira ${ }^{1 *}$, Raphael Ligeiro ${ }^{1}$, Diego R. Macedo ${ }^{1,2}$, \\ Robert M. Hughes ${ }^{3}$, Philip R. Kaufmann ${ }^{4}$, Leandro G. Oliveira ${ }^{5}$ \\ and Marcos Callisto ${ }^{1}$ \\ 1 Laboratório de Ecologia de Bentos, Departamento de Biologia Geral, Instituto de Ciências Biológicas, Universidade Federal de \\ Minas Gerais, Av. Antônio Carlos 6627, CP 486, CEP 31270-901, Belo Horizonte, Minas Gerais, Brazil \\ 2 Instituto Brasileiro de Geografia e Estatística, Rua Oliveira 523, CEP 30310-150, Belo Horizonte, Minas Gerais, Brazil \\ 3 Amnis Opes Institute and Department of Fisheries \& Wildlife, Oregon State University, 97331-4501, Corvallis, OR, USA \\ ${ }^{4}$ U.S. Environmental Protection Agency, Office of Research and Development, National Health and Environmental Effects Lab., \\ Western Ecology Division, 200 SW35 Street, 97333 Corvallis, OR, USA \\ 5 Departamento de Ecologia, Instituto de Ciências Biológicas, Universidade Federal de Goiás, Campus II, Samambaia CP. 131, \\ CEP. 74001-970 Goiânia, Goiás, Brazil
}

Received 27 December 2013; Accepted 21 December 2014

\begin{abstract}
Macroinvertebrates are important for processing leaf detritus in temperate streams, but studies about their role in tropical streams often present conflicting results. Via digestive tract analyses, we assessed the diets of Phylloicus sp. larvae (Trichoptera: Calamoceratidae), collected from streams of two southeastern Brazil river basins (Araguari, São Francisco). We classified gut contents as coarse particulate organic matter (CPOM), fine particulate organic matter (FPOM), algae, animal tissue, vascular plant tissue and mineral material. We hypothesized that the diets of Phylloicus larvae would be related to the physical habitat of the streams (e.g., riparian vegetation, organic matter availability and morphological characteristics), larval size and river basin. Although FPOM content predominated in both basins, we found greater CPOM content in Phylloicus larvae of Upper São Francisco sites, and this food item was related to greater riparian vegetation canopy density. The FPOM content was greater in larvae of Upper Araguari sites, and this food item was correlated with greater instream brush cover. Algae, animal tissue, vascular plant tissue and mineral material were very rare in the digestive tracts, and therefore could not be explained. These results indicate the importance of riparian vegetation structure in modulating feeding habitats of macroinvertebrates. We conclude that the Phylloicus larvae had more flexibility in what they eat than we might expect based on their traditional classification as shredders. Therefore, trusting in published classifications, ignoring regional or local differences, may be inaccurate. Instead, regional studies of feeding habits are needed for accurate classifications of invertebrate taxa into trophic guilds.
\end{abstract}

Key words: Gut contents / aquatic macroinvertebrates / trophic guilds / tropical streams / stream habitat conservation

\section{Introduction}

Organic matter from riparian vegetation is the main energy source for detritivorous aquatic organisms in headwater streams and the processing of that material is important for nutrient cycling and energy flow in aquatic ecosystems (Mathuriau and Chauvet, 2002; Gonç alves et al., 2006; Rincon and Martinez, 2006; Davies and Boulton, 2009). The riparian vegetation of Neotropical

\footnotetext{
*Corresponding author: ferreirawr@gmail.com
}

streams is rich in plant species, which generate an input of leaf detritus throughout the year (Cheshire et al., 2005; Carvalho and Uieda, 2009; Gonçalves and Callisto, 2013). Leaf decomposition in aquatic ecosystems occurs gradually through the actions of chemical, physical and biological agents (Gonçalves et al., 2007; França et al., 2009).

Detritivorous macroinvertebrates play an important role in the decomposition of leaves that fall and are transported and accumulated in stream bottoms. Shredder macroinvertebrates feed on those leaves (representing a major fraction of the coarse particulate organic 
matter - CPOM) and reduce their size, making them available in the form of fine particulate organic matter (FPOM) to other detritivorous organisms and decomposers (Boyero et al., 2011). Usually, shredders feed more readily upon leaves with less lignin, higher nutritional quality, greater conditioning by microorganisms and fewer toxic secondary compounds (Graça and Cressa, 2010; Jabiol et al., 2013).

The importance of shredder macroinvertebrates in the decomposition of $\mathrm{CPOM}$ in temperate regions has been well documented (Graça, 2001; Graça et al., 2001). Some authors have speculated that the abundance and diversity of shredders is higher in temperate streams than in tropical streams because these organisms are more adapted to lower temperatures (Yule et al., 2009; Boyero et al., 2011) and to the higher nutritional quality and palatability of $\mathrm{CPOM}$ in temperate regions (Graça, 2001; Davies and Boulton, 2009; Jabiol et al., 2013).

The role and relative importance of shredder macroinvertebrates in tropical streams are still under discussion (e.g., Gonçalves et al., 2006; Becker et al., 2009; Moretti et al., 2009; Boyero et al., 2011; Chara-Serna et al., 2012) and studies generate conflicting results. Some authors emphasized the importance of shredder macroinvertebrates in the dynamics of organic matter in tropical ecosystems (e.g., Motta and Uieda, 2004; Cheshire et al., 2005; Motta and Uieda, 2005). On the other hand, there are studies that point to the scarcity of shredders in tropical streams (Wantzen and Wagner, 2006; Gonçalves et al., 2007; Boyero et al., 2011), where bacteria and fungi are likely more important in the decomposition process (Graça, 2001; Mathuriau and Chauvet, 2002; Gonçalves et al., 2006).

High abundances of shredders in streams have been related to high riparian vegetation densities (Oliveira et al., 1999; Cummins et al., 2005). That is expected because physical habitat structure directly influences invertebrate assemblages, driving the shelter availability and food supply. In addition, the feeding behavior of individuals can change according to habitat conditions. Typical shredders assumed a collector-gatherer behavior responding to a current velocity increase, possibly because of energy constraints for capturing CPOM and the increased availability of fine detritus (Tomanova et al., 2006). Therefore, diets of the same taxon may vary because of regional or basin differences in riparian vegetation density and current velocities.

The diet of macroinvertebrates may vary also with life stage. For example, Malas and Wallace (1977) studied the strategies for coexistence in three species of caddisflies (Trichoptera) in second-order Appalachian streams and observed a greater proportion of fine particles in the early instars of two species (Dolophilodes sp. and Diplectrona sp.). Other studies of relating diet and larval size include Pinder (1986) and Casas (1996).

We assessed the diet of a typical tropical shredder (Phylloicus sp., Trichoptera, Calamoceratidae) through gut contents analyses. Our objective was to examine the relationship between the composition of food items in the guts of the larvae and the physical habitat characteristics in headwater streams of two different Cerrado (neotropical savanna) river basins. We hypothesized that the composition of food items would differ in Phylloicus larvae (1) of different size classes regardless of basin, (2) in response to differences in physical habitat (such as riparian vegetation, organic matter availability and stream morphology) regardless of basin, and (3) in response to basin differences in land use, channel slope, and riparian vegetation type and density. Following hierarchy theory, we also assumed that basin differences would affect Phylloicus diets through their effects on site habitat factors (Frissell et al., 1986; O'Neill et al., 1989; Tonn, 1990). Therefore, we sought to test whether prior trophic classifications long-accepted by macroinvertebrate researchers depend on the environmental context at multiple spatial scales.

\section{Methods}

\section{Study area}

The Cerrado is the second largest biome in Brazil and harbors considerable animal and plant biodiversity, with a high incidence of endemism. The landscape is dominated by four major vegetation types (woodland savanna, grassy-woody savanna, savanna park and wetland palm swamps), and dense vegetation usually occurs along undisturbed riparian corridors. At a global scale the Cerrado is considered a biodiversity hotspot (Myers et al., 2000). For over six decades, much of its natural vegetation has been replaced by pastures and row crops (Diniz-Filho et al., 2009). The removal of the riparian vegetation increases erosion, turbidity and bed sedimentation, water temperature and the abundance of aquatic macrophytes, leading to habitat simplification and affecting the distribution, richness and abundance of aquatic macroinvertebrates (Chapman and Chapman, 2002; Kaufmann et al., 2009; Hughes et al., 2010; Kaufmann and Faustini, 2012).

We studied 15 sites in first- to third-order streams (Strahler, 1957; map scale: 1:100,000), nine sites in the Upper São Francisco River Basin $\left(44^{\circ} 30^{\prime} 0^{\prime \prime} \mathrm{W}-46^{\circ} 0^{\prime} 0^{\prime \prime} \mathrm{W}\right.$; $\left.17^{\circ} 0^{\prime} 0^{\prime \prime} \mathrm{S}-19^{\circ} 30^{\prime} 0^{\prime \prime} \mathrm{S}\right)$ and six sites the Upper Araguari River Basin $\left(46^{\circ} 30^{\prime} 0^{\prime \prime} \mathrm{W}-48^{\circ} 0^{\prime} 0^{\prime \prime} \mathrm{W} ; 1^{\circ} 0^{\prime} 0^{\prime \prime} \mathrm{S}-20^{\circ} 0^{\prime} 0^{\prime \prime} \mathrm{S}\right)$ (Fig. 1). Both basins are located in the Cerrado biome of the State of Minas Gerais, southeastern Brazil, and they have similar climates (humid tropics and high altitude tropical). Site elevations ranged from 584 to $960 \mathrm{~m}$ a.s.l. The dry season lasts from May to September, with monthly rainfall between 10 and $55 \mathrm{~mm}$, and the rainy season lasts from October to April, with monthly rainfall between 100 and $300 \mathrm{~mm}$. The average annual rainfall is $1600 \mathrm{~mm}$ (Brasil, 1992). However the Upper São Francisco is drier, has more pasture and less row crop agriculture, and the riparian vegetation is often sparse compared with the Upper Araguari (Callisto et al., 2014). 


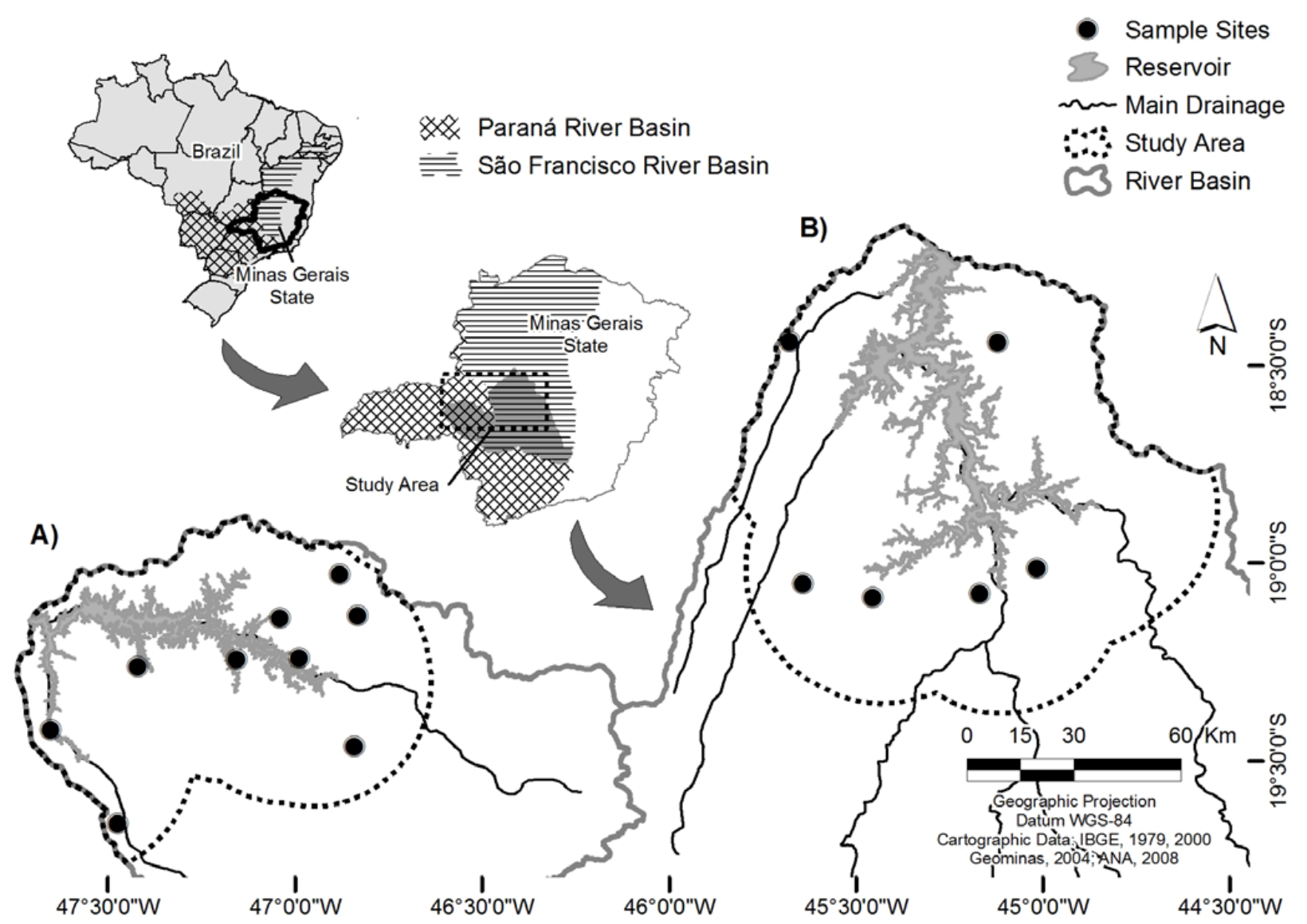

Fig. 1. Study area and location of sampling sites in the Upper Araguari River (A) and Upper São Francisco River (B) Basins, southeastern Brazil.

\section{Field sampling}

We sampled during the end of the dry season, in September 2009 and 2010, in the Upper Araguari River and Upper São Francisco River Basins, respectively. This sampling was part of a larger ecological study of 80 sites designed to assess the ecological condition of the two basins (Ligeiro et al., 2013; Callisto et al., 2014), but herein we focus only on the 15 sites where we collected Phylloicus larvae.

\section{Physical habitat measurements}

The length of each site was defined as the average width multiplied by 40 , with $150 \mathrm{~m}$ being the minimum length sampled. In each site, we established 11 equidistant transects, perpendicular to the stream, defining 10 longitudinal sections of the same length. In each transect, and along the sections, we measured physical habitat characteristics following Peck et al. (2006) likely to be related to the availability of food resources, including metrics of channel morphology (e.g., wetted width and depth, bankfull width and depth), riparian vegetation (e.g., presence and percentage of cover of arboreal canopy and understory), natural shelters in the channel (e.g., undercut banks, fallen trees and twigs, percentage of filamentous algae and macrophytes) and presence of organic material (e.g., plant detritus and leaf packs). For riparian vegetation metrics, we estimated ground layer to be all cover under $0.5 \mathrm{~m}$, middle layer to be all cover between 0.5 and $5 \mathrm{~m}$, and canopy to be all cover above $5 \mathrm{~m}$ (Peck et al., 2006). Over 200 metrics were calculated from the field physical habitat measurements (Kaufmann et al., 1999).

\section{Collection of benthic macroinvertebrates}

In each of the 11 transects we sampled benthic macroinvertebrates with a D-frame net $(30 \mathrm{~cm}$ wide, $500 \mu \mathrm{m}$ mesh) with an area of $0.09 \mathrm{~m}^{2}$, totaling $1 \mathrm{~m}^{2}$ of sampled area per site. We fixed the samples in the field in $4 \%$ formalin. In our laboratory, we washed the samples through a 500- $\mu \mathrm{m}$ sieve and sorted the organisms. We used current literature to classify macroinvertebrates as shredders (Merritt and Cummins, 1996; Cummins et al., 2005; Chara-Serna et al., 2012), thus providing a rough estimate of the proportion of shredders in the studied sites.

\section{Determination of size classes of Phylloicus larvae}

We related the larval size classes to the development instars, considering the width of the head capsule ( $\mathrm{mm})$, 
Table 1. Physical habitat metrics tested. Metrics selected by a best subsets procedure for use in multiple linear regression (MLR) models are marked with an asterisk.

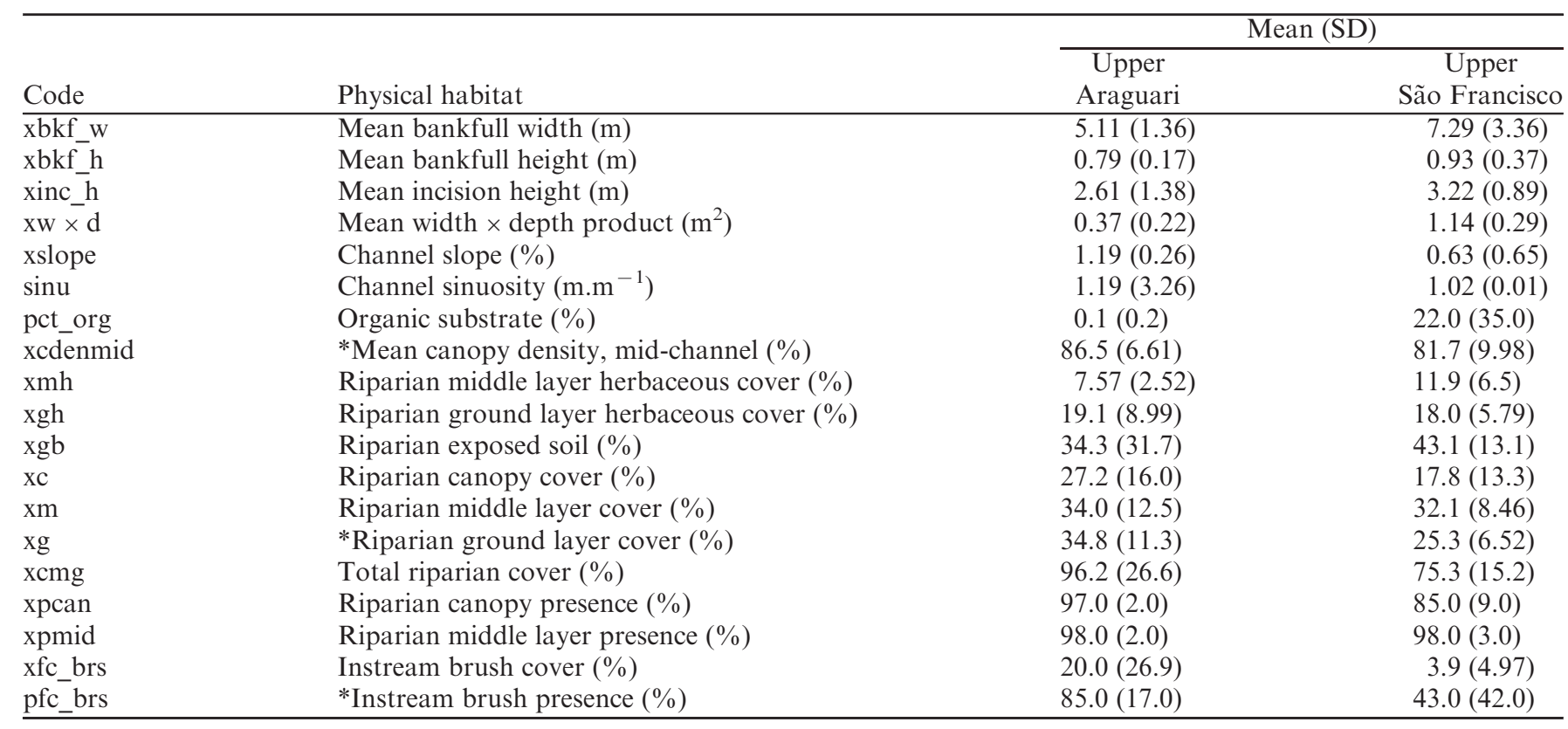

following Oliveira and Froehlich (1997). We measured the head capsules of all Phylloicus larvae collected $(n=96)$ under a Leica stereomicroscope (Model MSV266) with a magnification of $50 \mathrm{x}$. We examined and measured the larvae under low magnification $(5 \mathrm{x})$, and each micrometric unit (MU) was equal to $0.18 \mathrm{~mm}$. The results were expressed in $\mathrm{mm}$. We classified five larval instars (Oliveira and Froehlich, 1997) with the following head width ranges: $\mathrm{I}=2.52-3.06 \mathrm{~mm}$; $\mathrm{II}=3.07-5.76 \mathrm{~mm}$; $\mathrm{III}=5.77-$ $8.46 \mathrm{~mm}$; IV $=8.47-11.34 \mathrm{~mm}$; and $V \geq 11.35 \mathrm{~mm}$.

\section{Assessment of gut contents and quantification of food items}

We extracted larval digestive tracts through use of a scalpel under a stereoscopic microscope and we diluted and distributed the food items homogeneously on a Sedgewick Rafter gridded counting cell. The items were measured with the support of millimetric ocular reticules. Next, we separated and quantified the items (count per field) under the microscope at a magnification of $100 x$. We quantified the items using 20 random fields (Chara-Serna et al., 2012), which corresponded to $40 \%$ of the counting cells, and classified them into six categories following Cheshire et al. (2005). The categories were: CPOM $(>50 \mu \mathrm{m})$ mainly from leaves, FPOM ( $<50 \mu \mathrm{m})$, algae, vascular plant tissue (including roots), animal tissue (carapaces, cerci and legs) and mineral material. Note that the size of CPOM considered in the gut content analysis is much smaller than the average size of CPOM ( $>1 \mathrm{~mm}$ ) outside the guts (Cheshire et al., 2005).

\section{Data analysis}

\section{Variation of gut contents among instars}

To test for differences in the composition of food items in the gut contents of Phylloicus larvae among size classes (proportion of each item in each size class), we conducted a one-way ANOVA for each item, followed by a post-hoc Tukey's test. In those analyses, we considered only the individuals with food items in their gut contents $(n=72)$. For each food item, we arcsine-transformed data on the proportion of food items counted in the 20 random fields analyzed.

\section{Physical habitat and gut contents}

We used the Pearson product-moment correlation to exclude redundant metrics $(r>0.8)$, retaining the metrics that were ecologically more meaningful. For example, \% mean mid-channel canopy (xcdenmid) was strongly correlated with \% mean bank canopy (xcdenbk) $(r=0.88)$. Therefore, we chose the metric xcdenmid, because it was considered ecologically more comprehensive. Hence, we selected 19 physical habitat metrics for further analyses (Table 1). We used multiple linear regressions (MLR) to examine associations between the proportion of each food item counted and the physical habitat predictor variables. The proportion of each food item in each site was determined by averaging the proportions found in each individual larva. Again, we considered in those analyses only the 72 individuals with food items in their gut contents. Because we analyzed only 15 sites, we limited the final model to two predictor variables 

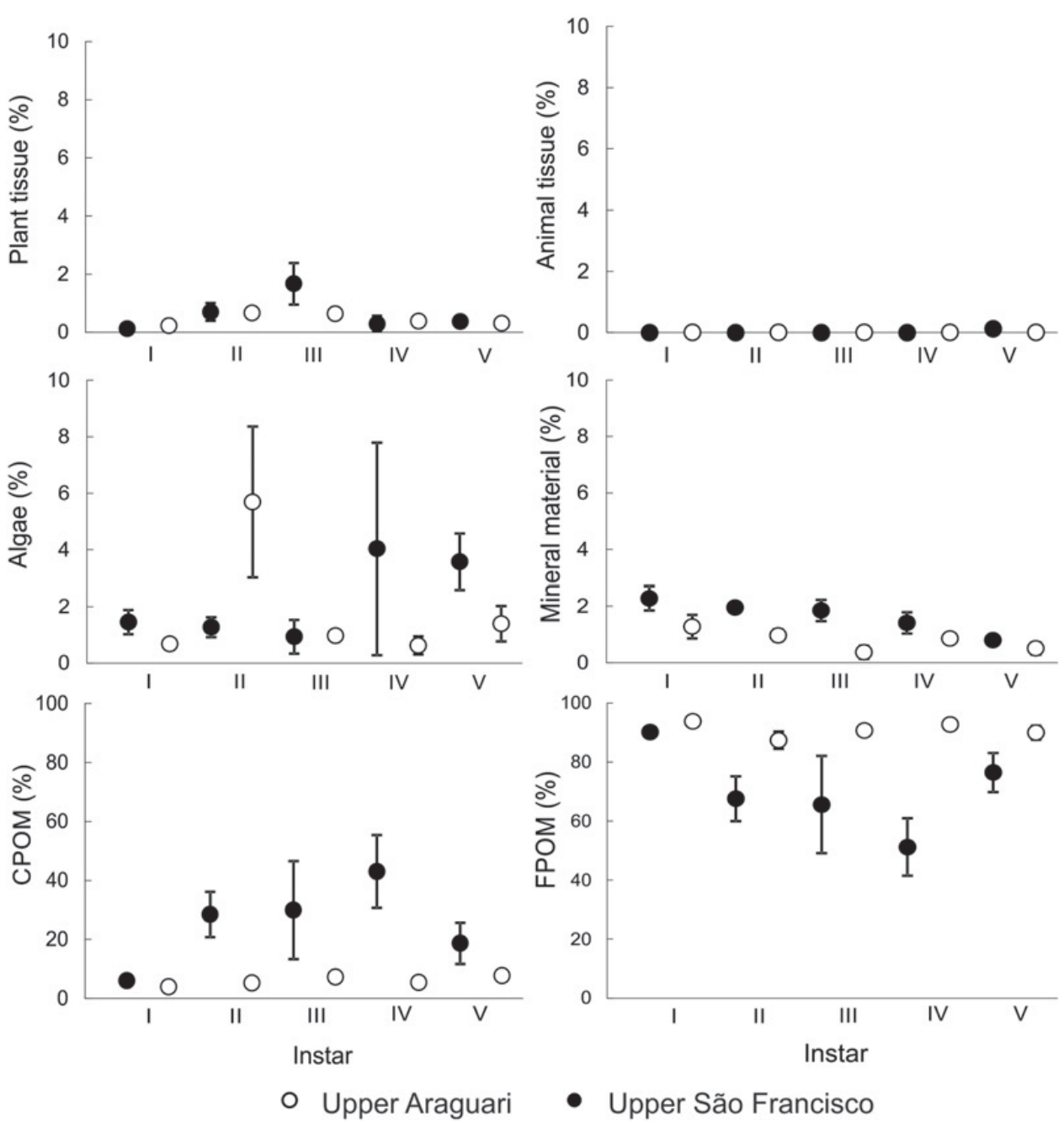

Fig. 2. Average proportion and standard error of the food items (proportion of fields in the counting cell with each item) for different Phylloicus larval instars in the Upper Araguari River and Upper São Francisco River Basins. Note the different scales in the Y-axes.

to avoid overfitting. We used the best subsets procedure (Harrell, 2001) for creating MLR models. In addition, we used the corrected Akaike information criteria (AICc) to search for the best models (Burnham and Anderson, 2002) and to verify whether the models could be simplified by reducing the number of explanatory variables in each case. When the difference between the AICc values of two models $(\triangle \mathrm{AICc})$ was $\leq 2$, the reduced model was considered equivalent and thus preferable. For these analyses, we used Systat for Windows (version 13.00.05, 2009).

\section{Basins and gut contents}

Because we obtained Phylloicus at a total of only 15 sites, we used all 15 sites together in the instar and physical habitat analyses, assuming that those site-scale factors would outweigh a basin effect because of hierarchy theory and small sample size. To evaluate a basin effect on the instar and habitat results, we simply graphed the instar and habitat results for the two basins separately and examined them.

\section{Results}

Shredder individuals represented $13 \%$ of all macroinvertebrate individuals collected from the 15 sites. We collected 96 Phylloicus larvae in the 15 studied streams; 50 larvae in 9 Upper Araguari River Basin sites and 46 larvae in Upper São Francisco River Basin sites. Of these, 22 individuals were in instar I, 14 in instar II, 5 in instar III, 8 in instar IV and 47 in instar V. We found food items in the digestive tracts of 72 of the Phylloicus larvae (33 in the Upper Araguari and 39 in the Upper São Francisco), corresponding to $75 \%$ of all Phylloicus larvae collected; that is, in $25 \%$ of the larvae either there was no food or the digestive tract was damaged. The body length of the larvae ranged from 3.0 to $18.0 \mathrm{~mm}$.

FPOM and CPOM were the predominant food items, and together represented over $90 \%$ of the gut contents of the larvae. Gut FPOM differed among instars $\left(F_{4,72}=\right.$ $3.85 ; P=0.007)$, and it was more common in the Upper Araguari River Basin (Fig. 2). Gut CPOM also differed among instars $\left(F_{4,72}=3.35 ; P=0.015\right)$, but it was more common in the Upper São Francisco River Basin (Fig. 2). 
Table 2. Multiple linear regressions (best subsets) that explain the composition of food items of Phylloicus larvae in the Upper Araguari River Basin and the Upper São Francisco River Basin.

\begin{tabular}{|c|c|c|c|c|c|c|c|}
\hline Sites & Food content & Model & Predictor metrics & Beta & Beta standard error & $\mathrm{AICc}$ & $\triangle \mathrm{AICc}$ \\
\hline \multirow{10}{*}{$\begin{array}{l}\text { Combined model } \\
\text { of the Upper } \\
\text { Araguari and } \\
\text { Upper São } \\
\text { Francisco Basins }\end{array}$} & \multirow[t]{5}{*}{ CPOM } & \multirow[t]{3}{*}{ Two variables } & xcdenmid & 0.24 & 0.19 & \multirow[t]{3}{*}{-18.61} & \multirow[t]{5}{*}{1.12} \\
\hline & & & pfc_brs & -0.58 & 0.19 & & \\
\hline & & & & $R^{2}$ adj. $=0.50$ & $F_{2,12}=8.13$ & & \\
\hline & & \multirow[t]{2}{*}{ One variable } & pfc_brs & -0.29 & -0.71 & \multirow[t]{2}{*}{-19.73} & \\
\hline & & & & $R^{2}$ adj. $=0.48$ & $F_{1,13}=13.95$ & & \\
\hline & \multirow[t]{5}{*}{ FPOM } & Two variables & $x g$ & 0.59 & 0.19 & \multirow[t]{3}{*}{-16.56} & \multirow[t]{5}{*}{0.39} \\
\hline & & & pfc_brs & 0.33 & 0.19 & & \\
\hline & & & & $R^{2}$ adj. $=0.57$ & $F_{2,12}=10.16$ & & \\
\hline & & One variable & $x g$ & 0.73 & 0.18 & \multirow[t]{2}{*}{-16.95} & \\
\hline & & & & $R^{2}$ adj. $=0.50$ & $F_{1,13}=14.88$ & & \\
\hline
\end{tabular}

See Table 1 for metric definitions.

FPOM was the main food item of larvae of all instars collected in the Upper Araguari River Basin sites, followed by CPOM (Fig. 2). The lowest percentage of FPOM (86\%) was found in instar II and the highest percentage $(94 \%)$, in instar I. The highest percentage of CPOM was found in instar III $(7.4 \%)$ and the lowest in instar I (3.6\%). The highest percentage of algae was found in instar II $(7.3 \%)$ and the lowest in instar IV $(0.6 \%)$. In this basin, fragments of animal tissue, plant tissue, algae and mineral material were very rare $(<0.2 \%)$ in the digestive tracts of Phylloicus larvae.

In the Upper São Francisco River Basin sites, FPOM was also the main type of food in all larval instars, followed by CPOM (Fig. 2). The highest percentage of FPOM was found in instar I (90.5\%) and the lowest (50.5\%) in instar IV. The highest percentage of CPOM was found in instar IV $(42.4 \%)$ and the lowest in instar I $(5.6 \%)$. In this basin, other food items and mineral material were also rare in the digestive tract of Phylloicus larvae $(<6.0 \%)$.

There were no significant differences in the proportions of mineral material, algae, plant tissue and animal tissue among the digestive tracts of the different larvae instars, all those items being very scarce in both basins (Fig. 2).

Percent instream brush presence (pfc_brs), referring to smaller wood pieces that provide concealment for macroinvertebrates, and mean percent canopy density measured mid-channel (xcdenmid) were the two metrics selected by the best subsets procedure to explain CPOM proportions in the gut content of the larvae (adjusted $R^{2}=0.50$, Table 2). However, the corrected Akaike criteria suggested that this model could be simplified to one explanatory variable, instream brush presence ( $\%)$ (adjusted $R^{2}=0.48$ ) (Fig. 3). Instream brush cover presence and riparian ground layer cover $(\%)(\mathrm{xg})$ were selected to explain FPOM proportions (adjusted $R^{2}=0.57$, Table 2). Again, the AICc suggested that this model could be simplified to one explanatory variable, riparian ground layer cover (adjusted $R^{2}=0.50$, Table 2) (Fig. 3). We did not analyze the other items through multiple regressions because these items were very rare in the larval digestive tracts. It is likely that they were consumed accidentally by a few individuals and were unreliable for establishing causal relationships between their proportions and the physical habitat.

\section{Discussion}

\section{Abundance of macroinvertebrate shredders in the Cerrado}

The relatively low abundance of typical shredders $(13 \%)$ in the studied sites corroborates the literature (Wantzen and Wagner, 2006; Gonçalves et al., 2007; Boyero et al., 2011). However, Brazil is a country with a wide variety of biomes, such as Atlantic Forest, Amazon Forest, Caatinga, Pampa, Cerrado and Pantanal (IBGE, 1991). Hence, the abundance and importance of shredders likely differs among biomes because of differing food availability and physical habitat characteristics. Ferreira et al. (2014) showed the importance of physical habitat in the distribution of the richness of Ephemeroptera, Plecoptera and Trichoptera (EPT) individuals in the Cerrado biome. Oliveira et al. (1999) observed a high abundance of Trichoptera shredders in Amazon Basin streams with dense riparian vegetation. Baptista et al. (2007), in an assessment of environmental quality in Atlantic Forest streams, developed a benthic multimetric index and concluded that shredder abundance was high in reference sites, and related to their physical habitat. In contrast, Ferreira et al. (2011) observed a low abundance of shredders in Cerrado streams.

\section{Food resource use and availability}

Our study showed the importance of assessing the diets of different instars of Phylloicus larvae to understand changes in the composition and proportion of food items among the different life stages of these organisms. Accordingly, Malas and Wallace (1977) found that Trichoptera larvae at various stages of life tend to eat different sizes and types of particles, and that serves as an important mechanism to reduce inter and intra-specific competition.

Traditionally, the classification of stream macroinvertebrates into functional feeding groups is based on the examination of mouth parts and feeding habits, but such classifications can be imprecise (Mihuc and Mihuc, 1995). Boyero et al. (2011) argued that macroinvertebrate larvae 

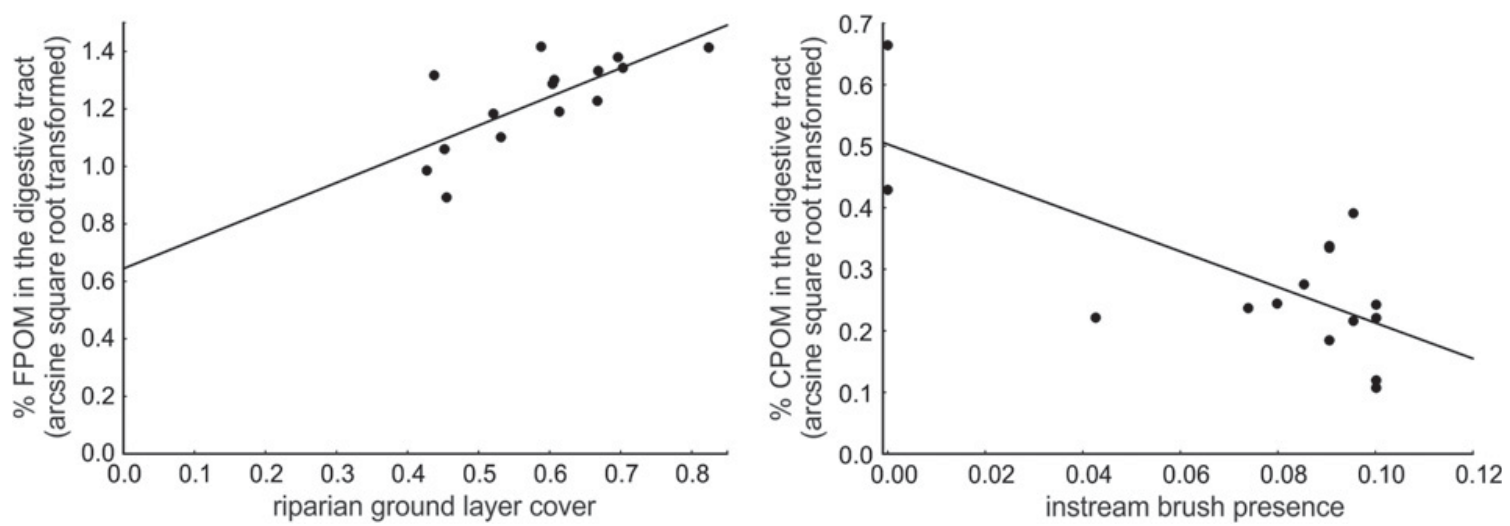

Fig. 3. Scatterplots of relationship of FPOM proportion versus riparian ground layer cover and CPOM proportion versus instream brush presence.

can be classified as shredders solely by their gut content analysis. Because Phylloicus larvae are considered typical shredders, we expected to find a predominance of CPOM in the digestive tract of the larvae. However, we found that, among the six food items assessed, FPOM predominated in all instars. Thus, our results suggest that Phylloicus larvae exhibited plasticity in their dietary behavior. Callisto and Graça (2013) reported similar results. It is usually accepted that stream macroinvertebrates exhibit plasticity in their feeding habitats, being considered generalists in many cases (Friberg and Jacobsen, 1994; Mihuc and Minshall, 1995; Carvalho and Graça, 2007; Moretti et al., 2009). In a laboratory experiment concerning specialist and generalist behavior in food assimilation, Mihuc and Mihuc (1995) found that among the five species classified as shredders, four exhibited generalist behavior, with biomass increasing after consuming three types of food (CPOM, FPOM and periphyton). Only one species showed specialist behavior and grew strictly with the consumption of CPOM.

Although we are not totally sure that all individuals collected belonged to the same species, this does not affect our analyses considering that all larvae showed the same types of food items in their gut contents, their proportions differing among the two basins studied. Phylloicus larvae in the Upper Araguari River Basin were mainly collectorgatherers, whereas those in the Upper São Francisco River Basin were collector-gatherers/shredders. Other studies have found that this shift in larval feeding behavior can be related to the availability of each food resource in each situation. For instance, Carvalho and Graça (2007) showed in a laboratory experiment that Seriscotoma vittatum (Trichoptera, Sericostomatidae) larvae demonstrated feeding plasticity depending on the amounts of CPOM and FPOM offered to the larvae. Tomanova et al. (2006) observed that the availability of CPOM and FPOM in a tropical Bolivian stream was influenced by physical abrasion of water flow and microbial activity. In those environments, that rapid processing of organic matter resulted in higher amounts of FPOM relative to CPOM. In their study, the typical shredder genus Andesiops (Ephemeroptera, Baetidae) was considered a collector-gatherer because of the high proportion of FPOM found in its digestive tract, similar to the Phylloicus larvae from the Upper Araguari River Basin in our study. However, further studies with markedly more sites are needed to confirm whether there are statistically significant differences in CPOM and FPOM between the basins and whether those could account for the differences in Phylloicus larval feeding.

\section{Relationships between stream physical habitat and food items in digestive tracts}

Previous studies have shown that the complexity of site-scale physical habitat influences the composition, biomass and richness of benthic macroinvertebrates, the temporal stability of assemblages, and ecological processes including nutrient and hydrologic retention (Hughes et al., 2010; Kaufmann and Faustini, 2012; Kovalenko et al., 2012). Quinn and Hickey (1990) observed greater shredder biomass in streams with greater riparian vegetation densities. We also demonstrated that changes in physical habitat characteristics, such as instream brush cover and riparian vegetation, can also influence the diet of longconsidered typical shredders.

The AICc supported a single explanatory metric in our MLR models, but we also discuss here the importance of the other metrics selected in the full models. We found that CPOM in larval digestive tracts was positively correlated with riparian vegetation canopy density and negatively correlated with instream brush presence availability (Table 2 and Fig. 3). The first relationship was expected because greater canopy density usually represents greater CPOM availability for the streams, mainly in the form of leaf detritus (Vannote et al., 1980; Boyero et al., 2011; Chara-Serna et al., 2012). A previous study by Cummins et al. (2005) found a positive relation between abundance of shredders and density of riparian vegetation. Our results corroborate theirs because the feeding behavior of Phylloicus, assessed by gut analysis, was also related to the density of the riparian vegetation canopy. In contrast, instream brush presence was positively correlated with gut 
FPOM. This suggests that instream brush may have been trapping and accumulating fine organic particles (Ehrman and Lamberti, 1992; Webster et al., 1999, Horvath, 2004), which facilitated macroinvertebrate access to this material. FPOM also had a positive correlation with ground layer riparian vegetation. This relationship indicates the importance of measuring multiple riparian vegetation layers when assessing the availability of trophic resources in stream food webs (Naiman et al., 2005; Allan and Castillo, 2007).

\section{Conclusion}

Although Phylloicus is often considered a typical shredder, we found that the larvae collected in the two studied basins consumed more FPOM than CPOM, that the relative amounts of FPOM and CPOM consumed varied significantly by instars, and that the proportion of food items in larval digestive tracts were significantly related to stream physical habitat characteristics. Thus, our study re-emphasizes that classifying aquatic macroinvertebrates into functional feeding groups may incorporate considerable error. It would be useful to analyze digestive tract contents of taxa from multiple basins and ecoregions to determine the degree of dietary flexibility of shredders, and to determine how common it is for them to specialize on CPOM feeding.

Acknowledgements. We are grateful to the Peixe-Vivo Program of Companhia Energética de Minas Gerais, Pesquisa \& Desenvolvimento/Agência Nacional de Energia Elétrica/ Companhia Energética de Minas Gerais-P\&D ANEEL/ CEMIG (GT-487), Coordenação de Aperfeiçoamento de Pessoal de Nível Superior, Conselho Nacional de Desenvolvimento Científico e Tecnológico (CNPq), Fundação de Amparo à Pesquisa do Estado de Minas Gerais (FAPEMIG), and Fulbright-Brasil for financial support; Carlos Bernardo Mascarenhas Alves for logistical support; colleagues from the Federal University of Minas Gerais Benthic Ecology Laboratory, Federal Center of Technological Education of Minas Gerais, Federal University of Lavras, and Pontifical Catholic University of Minas Gerais for help with field collections; and researchers at the U.S. EPA Western Ecology Division, Corvallis, Oregon for discussions during an October 2011 workshop. MC received CNPq research grant and research fellowship nos. 471385/2011-5 and 302960/2011-2 and FAPEMIG research grant PPM-00077/13. Tony Olsen, Marc Weber, and Phil Larsen of the Corvallis US Environmental Protection Agency Laboratory (Oregon, USA) kindly assisted in developing spatial sampling designs and selecting wadeable stream sample sites. The manuscript was improved via reviews by William Gerth of Oregon State University, and four anonymous referees. This manuscript was subjected to review by the US EPA National Health and Environmental Effects Research Laboratory's Western Ecology Division and approved for publication. Approval does not signify that the contents reflect the views of the Agency, nor does mention of trade names or commercial products constitute endorsement or recommendation for use.

\section{References}

Allan J.D. and Castillo M.M., 2007. Stream Ecology: Structure and Function of Running Waters (2nd edn,), Springer, Dordrecht, Netherlands, $435 \mathrm{p}$.

Baptista D.F., Buss D.F., Egler M., Giovanelli A., Silveira M.P. and Nessimian J.L., 2007. A multimetric index based on benthic macroinvertebrates for evaluation of Atlantic Forest streams at Rio de Janeiro State, Brazil. Hydrobiologia, 575, 83-94.

Becker B., Moretti M.S. and Callisto M., 2009. Length-dry mass relationships for a typical shredder in Brazilian streams (Trichoptera: Calamoceratidae). Aquat. Insects, 31, 227-234.

Boyero L., Pearson R.G., Dudgeon D., Graça M.A.S., Gessner M.O., Albariño R.J., Ferreira V., Yule C.M., Boulton A.J., Arunachalam M., Callisto M., Chauvet E., Ramírez A., Chará J., Moretti M.S., Gonçalves J.F. Jr, Helson J.E., Chará-Serna A.M., Encalada A.C., Davies J.N., Lamothe S., Cornejo A., Li A.O.Y., Buria L.M., Villanueva V.D., Zúñiga M.C. and Pringle C.M., 2011. Global distribution of a key trophic guild contrasts with common latitudinal diversity patterns. Ecology, 92, 1839-1848.

Brasil, 1992. Normais Climatológicas (1960-1990), Brasília: Ministério da Agricultura e Reforma Agrária, Secretaria Nacional de Irrigação, Departamento Nacional de Meteorologia, Brasília, 84 p.

Burnham K. and Anderson D., 2002. Model Selection and Multimodel Inference: A Practical Information-Theoretical Approach, Springer, New York.

Callisto M. and Graça M.A.S., 2013. The quality and availability of fine particulate organic matter for collector species in headwater streams. Int. Rev. Hydrobiol., 98, 132-140.

Callisto M., Hughes R.M., Lopes J.M. and Castro M.A. (eds.), 2014. Ecological Conditions in Watersheds of Hydropower Dams, Série Peixe Vivo 2. Companhia Energética de Minas Gerais, Belo Horizonte, Minas Gerais, 213 p.

Carvalho E.M. and Graça M.A.S., 2007. A laboratory study on feeding plasticity of the shredder Sericostoma vittatum Rambur (Sericostomatidae). Hydrobiologia, 575, 353-359.

Carvalho E.M. and Uieda V.S., 2009. Diet of invertebrates sampled in leaf-bags incubated in a tropical headwater stream. Zoologia (Curitiba), 26, 694-704.

Casas J.J., 1996. The effect of diet quality on growth and development of recently hatched larvae of Chironumus $\mathrm{gr}$. plumosus. Limnética, 12, 1-8.

Chapman L. and Chapman C., 2002. Tropical forest degradation and aquatic ecosystems: our current state of knowledge. In: Collares-Pereira M.J., Cowx I.G. and Coelho M.M. (eds.), Conservation of Freshwater Fishes: Options for the Future, Blackwell Science, Oxford, 237-249, 472 p.

Chara-Serna A.M., Chara J.D., Zuniga M.D., Pearson R.G. and Boyero L., 2012. Diets of leaf litter-associated invertebrates in three tropical streams. Ann. Limnol. - Int. J. Lim., 48, 139-144.

Cheshire K., Boyero L. and Pearson R.G., 2005. Food webs in tropical Australian streams: shredders are not scarce. Freshwat. Biol., 50, 748-769.

Cummins K.W., Merritt R.W. and Andrade P.C.N., 2005. The use of invertebrate functional groups to characterize ecosystem attributes in selected streams and rivers in South Brazil. Stud. Neotrop. Fauna Environ., 40, 69-89. 
Davies J.N. and Boulton A.J., 2009. Great house, poor food: effects of exotic leaf litter on shredder densities and caddisfly growth in 6 subtropical Australian streams. J. N. Am. Benthol. Soc., 28, 491-503.

Diniz-Filho J.A.F., Bini L.M., Oliveira G., Barreto B.S., Silva M.M.F.P., Terribile L.C., Rangel T.F.L.V.B., Pinto M.P., Sousa N.P.R., Vieira L.C.G., Melo A.S., Marco Júnior P.P., Vieira C.M., Blamires D., Bastos R.P., Carvalho P., Ferreira L.G., Telles M.P.C., Rodrigues F.M., Silva D.M., Silva N.J. Jr and Soares T.N., 2009. Macroecology, biogeography and priority areas for conservation in the Brazilian Cerrado. Oecol. Bras., 13, 470-497.

Ehrman T.P. and Lamberti G.A., 1992. Hydraulic and particulate matter retention in a 3rd-order Indiana stream. J. N. Am. Benthol. Soc., 11, 341-349.

Ferreira W., Paiva L. and Callisto M., 2011. Development of a benthic multimetric index for biomonitoring of a neotropical watershed. Braz. J. Biol., 71, 15-25.

Ferreira W.R., Ligeiro R., Macedo D.R., Hughes R.M., Kaufmann P.R., Oliveira L.G. and Callisto M., 2014. Importance of environmental factors on the richness and distribution of benthic macroinvertebrates in tropical headwater streams. Freshwat. Sci., 33, 860-871.

França J.S., Gregório R.S., Paula J.D.A., Gonçalves J.F.J., Ferreira F.A. and Callisto M., 2009. Composition and dynamics of allochthonous organic matter inputs and benthic stock in a Brazilian stream. Mar. Freshwat. Res., 60, 990-998.

Friberg N. and Jacobsen D., 1994. Feeding plasticity of two detrivore-shredders. Freshwat. Biol., 32, 133-142.

Frissell C.A., Liss W.J., Warren C.E. and Hurley M.D., 1986. A hierarchical framework for stream habitat classification: viewing streams in a watershed context. Environ. Manage, 10, 199-214.

Gonçalves J.F.J. and Callisto M., 2013. Organic-matter dynamics in the riparian zone of a tropical headwater stream in Southern Brasil. Aquat. Bot., 109, 8-13.

Gonçalves J.F.J., Graça M.A.S. and Callisto M., 2006. Leaflitter breakdown in 3 streams in temperate, Mediterranean, and tropical Cerrado climates. J. N. Am. Benthol. Soc., 25, 344-355.

Gonçalves J.F.J., Graça M.A.S. and Callisto M., 2007. Litter decomposition in a Cerrado savannah stream is retarded by leaf toughness, low dissolved nutrients and a low density of shredders. Freshwat. Biol., 52, 1440-1451.

Graça M.A.S., 2001. The role of invertebrates on leaf litter decomposition in streams - A review. Int. Rev. Hydrobiol., 86, 383-393.

Graça M.A.S. and Cressa C., 2010. Leaf quality of some tropical and temperate tree species as food resource for stream shredders. Int. Rev. Hydrobiol., 95, 27-41.

Graça M.A.S., Cressa C.M.O.G., Gessner T.M.O., Feio M.J., Callies K.A. and Barrios C., 2001. Food quality, feeding preferences, survival and growth of shredders from temperate and tropical streams. Freshwat. Biol., 46, 947-957.

Harrell F.E., 2001. Regression Modeling Strategies: With Applications to Linear Models, Logistic Regression, and Survival Analysis, Springer, New York, 333 p.

Horvath T.G., 2004. Retention of particulate matter by macrophytes in a first-order stream. Aquat. Bot., 78, 27-36.

Hughes R.M., Herlihy A.T. and Kaufmann P.R., 2010. An evaluation of qualitative indexes of physical habitat applied to agricultural streams in ten U.S. States. J. Amer. Wat. Resour. Assoc., 46, 792-806.

IBGE - Instituto Brasileiro de Geografia e Estatística, 1991. Manual Técnico da Vegetação Brasileira, Rio de Janeiro, Brasil, 92 p.

Jabiol J., McKie B.G., Bruder A., Bernadet C., Gessner M.O. and Chauvet E., 2013. Trophic complexity enhances ecosystem functioning in an aquatic detritus -based model system. J. Animal Ecol., 82, 1042-1051.

Kaufmann P.R. and Faustini J.M., 2012. Simple measures of channel habitat complexity predict transient hydraulic storage in streams. Hydrobiologia, 685, 69-95.

Kaufmann P.R., Levine P., Robison E.G., Seeliger C. and Peck D.V., 1999. Quantifying Physical Habitat in Wadeable Streams, EPA 620/R-99/003 Environmental Monitoring and Assessment Program, US Environmental Protection Agency, Corvallis, OR, 149 p.

Kaufmann P.R., Larsen D.P. and Faustini J.M., 2009. Bed stability and sedimentation associated with human disturbances in Pacific Northwest streams. J. Amer. Wat. Resour. Assoc., 45, 434-459.

Kovalenko K.E., Thomaz S.M. and Warfe D.M., 2012. Habitat complexity: approaches and future directions. Hydrobiologia, $685,1-17$.

Ligeiro R., Hughes R.M., Kaufmann P.R., Macedo D.R., Firmiano K.R., Ferreira W.R., Oliveira D., Melo A.S. and Callisto M., 2013. Defining quantitative stream disturbance gradients and the additive role of habitat variation to explain macroinvertebrate taxa richness. Ecol. Indicat., 25, 45-57.

Malas D. and Wallace J.B., 1977. Strategies for coexistence in three species of net-spinning caddisflies (Trichoptera) in second-order southern Appalachian streams. Can. J. Zool., 55, 1829-1840.

Mathuriau C. and Chauvet E., 2002. Breakdown of leaf litter in a neotropical stream J. N. Am. Benthol. Soc., 21, 384-396.

Merritt R.W. and Cummins K.W. (eds.), 1996. An Introduction to the Aquatic Insects of North America (3rd edn), Kendall Hunt, Dubuque, Lowa, 862 p.

Mihuc T.B. and Mihuc J.R., 1995. Trophic ecology of five shredders in a rocky mountain stream. J. Freshwat. Ecol., 10, 209-216.

Mihuc T.B. and Minshall G.W., 1995. Trophic generalists vs. trophic specialists: implications for food web dynamics in post-fire streams. Ecology, 76, 2361-2372.

Moretti M.S., Loyola R.D., Becker B. and Callisto M., 2009. Leaf abundance and phenolic concentrations codetermine the selection of case-building materials by Phylloicus sp. (Trichoptera, Calamoceratidae). Hydrobiologia, 630, 199-206.

Motta R.L. and Uieda V.S., 2004. Diet and trophic groups of an aquatic insect community in a tropical stream. Braz. J. Biol., 64, 809-817.

Motta R.L. and Uieda V.S., 2005. Food web structure in a tropical stream ecosystem. Austral Ecol., 30, 58-73.

Myers N., Mittermeier R.A., Mittermeier C.G., Da Fonseca G.A. and Kent J., 2000. Biodiversity hotspots for conservation priorities. Nature, 403, 853-858.

Naiman R., Decamps H. and McClain M., 2005. Riparia: Ecology, Conservation and Management of Streamside Communities, Elsevier, Academic Press, Burlington, USA, $448 \mathrm{p}$. 
Oliveira L., Bispo P., Crisci V. and Sousa K., 1999. Distribuições de categorias funcionais alimentares de larvas de Trichoptera (Insecta) em uma região serrana do Brasil Central. Acta Limnol. Brasil., 11, 173-183.

Oliveira L.G. and Froehlich C.G., 1997. Diversity and community structure of aquatic insects (Ephemeroptera, Plecoptera and Trichoptera) in a mountain stream in Southeastern Brazil. Acta Limnol. Brasil., 9, 139-148.

O'Neill R., Johnson A. and King A., 1989. A hierarchical framework for the analysis of scale. Landscape Ecol., 3, 193-205.

Peck D.V., Herlihy A.T., Hill B.H., Hughes R.M., Kaufmann P.R., Klemm D.J., Lazorchak J.M., McCormick F.H., Peterson S.A., Ringold P.L., Magee T. and Cappaert M.R., 2006. Environmental Monitoring and Assessment Program Surface Waters. Western Pilot Study: field operations manual for wadeable streams. EPA Report EPA EPA/620/R-06/003. U.S. Environmental Protection Agency, Washington, DC, $331 \mathrm{p}$.

Pinder L.C.V., 1986. Biology of freshwater Chironomidae. Ann. Rev. Entomol., 31, 1-23.

Quinn J.M. and Hickey C.W., 1990. Characterisation and classification of benthic invertebrate communities in 88 New Zealand rivers in relation to environmental factors. $N$. Z. J. Mar. Freshwat. Res., 24, 387-409.
Rincon J. and Martinez F., 2006. Food quality and feeding preferences of Phylloicus sp. (Trichoptera: Calamoceratidae). J. N. Am. Benthol. Soc., 25, 209-215.

Strahler A.N., 1957. Quantitative analysis of watershed geomorphology. Trans. Amer. Geophys. Union, 38, 913-920.

Tomanova S., Goitia E. and Helešic J., 2006. Trophic levels and functional feeding groups of macroinvertebrates in neotropical streams. Hydrobiologia, 556, 251-264.

Tonn W.M., 1990. Climate change and fish communities: a conceptual framework. Trans. Amer. Fish. Soc., 119, 337-352.

Vannote R.L., Minshall G.W., Cummins K.W., Sedell J.R. and Cushing C.E., 1980. The river continuum concept. Can. J. Fish. Aquat. Sci., 37, 130-137.

Wantzen K.M. and Wagner R., 2006. Detritus processing by invertebrate shredders: a neotropical-temperate comparison. J. N. Am. Benthol. Soc., 25, 216-232.

Webster J.R., Benfield E.F., Ehrman T.P., Schaeffer M.A., Tank J.L., Hutchens J.J. and D'Angelo D.J., 1999. What happens to allochthonous material that falls into streams? A synthesis of new and published information from Coweeta. Freshwat. Biol., 41, 687-705.

Yule C.M., Leong M.Y., Liew K.C., Ratnarajah L., Schmidt K., Wong H.M., Pearson R.G. and Boyero L., 2009. Shredders in Malaysia: abundance and richness are higher in cool upland tropical streams. J. N. Am. Benthol. Soc., 28, 404-415. 